ISSN 2519-2523 (print)

DOI: $10.18524 / 2519-2523.2020 .15 .218674$

УДК 94(477.74):271.2“1800/1900”

\title{
THE HISTORY OF THE DEVELOPMENT OF THE ODESSA TEMPLE KAZAN ICON OF THE MOTHER OF GOD
}

\author{
Natalia Dianova \\ ORCID: https://orcid.org/0000-0003-0406-6907 \\ DSc (History), Professor \\ Odessa I.I. Mechnikov National University \\ 2, Dvoryanskaya str., Odessa, 65082, Ukraine \\ dianova@onu.edu.ua
}

The purpose of the presented work is to highlight some aspects of the development of the Odessa Church of the Kazan Icon of the Mother of God in the context of its achievements and problems in the period of the XVIII - the end of the XX century. The use of descriptive and retrospective research methods made it possible to reproduce the vast majority of historical stories associated with the development of the temple.

The article analyzes the features of the process of preparation and construction of a Cossack church on Peresyp. The complex of archival documents used in this work makes it possible to reconstruct the development of the parish from the beginning of the XVIII century to 1920. The role of the inhabitants of the suburb and the clergy in the process of the development of the temple is studied. It was emphasized that the church made significant achievements in the late 19th-early 20th centuries. A significant role in this process was played by the priests $F$. Chemena, I. Shramkov, A.Gentus, N. Cheredyev and others.

It is indicated that in the history of the temple of the Kazan Icon of the Mother of God of the 20th century several periods can be distinguished: the heyday of the temple at the beginning of the century, the repressions of 1920-1930, the opening of the temple and the resumption of services during the Second World War, the confiscation of the premises in the early 1960 and finally, the return of the temple to believers in 1991.

Key words: Odessa, Peresyp, Cossacks, the temple of the Kazan Icon of the Mother of God, clergy.

Наталія Діанова

ORCID: https://orcid.org/0000-0003-0406-6907

Доктор історичних наук, професор Одеський національний університет імені I.I. Мечникова

Вул. Дворянська, 2, м. Одеса, 65082, Україна dianova@onu.edu.ua

\section{ІСТОРІЯ РОЗБУДОВИ ОДЕСЬКОГО ХРАМУ КАЗАНСЬКОЇ ІКОНИ БОЖОЇ МАТЕРІ}

Мета статті полягає у висвітленні основних аспектів розбудови Одеського храму Казанської ікони Божої Матері в контексті його досягнень та проблем упродовж XVIII кіния XX cm. Використання дескриптивного та ретроспективного методів дослідження дало можливість відтворити переважну більшість історичних сюжетів, пов'язаних із процесом розбудови храму. 
У статті проаналізовано особливості процесу підготовки та будівництва козацької церкви на Пересипу. Використаний у роботі комплекс архівних документів дає можливість реконструювати розвиток парафії з початку XVIII cm. до 1920 р. Досліджено роль жителів передмістя та духовенства в прочесі розбудови храму. Зазначено, що значних здобутків церква досягла наприкіниі XIX - на початку XX cm. Вагому роль у иьвому прочесі відіграли священики: Ф. Чемена, І. Шрамков, А. Гентус, М. Чередєєв та інші.

Наголошено, щчо в історії храму Казанської ікони Божої Матері XX cm. можна виокремити декілька періодів: розквіт на початку століття, репресіі 1920-1930 рр., відкриття храму $і$ відновлення богослужінь у період Другої світової війни, конфіскачія приміщення на початку 1960-х рр. i, нарешті, повернення храму віруючим у 1991 p.

Ключові слова: Одеса, Пересип, козачтво, храм Казанської ікони Божої Матері, духовенство.

Історія розбудови Одеського храму Казанської ікони Божої Матері, що знаходиться на Пересипу, безпосередньо пов'язана 3 козаками, що здавна проживали в цьому передмісті. Тож не даремно його називали спочатку козацьким або чорноморським, тому що частина козаків до поселення в місті належала до Чорноморської гребної флотилії. Коли внаслідок російсько-турецької війни (17871791 рр.) турецька фортеця Хаджибей відійшла до Російської імперії, а на іiї місці розпочалося активне будівництво міста-порту, то першими його жителями стали козаки й українські селяни, які раніше проживали в передмісті чи околицях фортеці, та чорноморські козаки, що були у Чорноморській гребній флотилії Й. Дерибаса. Останні утворили особливу слобідку або передмістя на Пересипу. У 1797 рр. козаки, що входили з 1794 р. до Чорноморської козацької команди на чолі з осавулом Ф. Черненко, отримали дозвіл на постійне проживаня в місті. Вони були приписані до станів одеських міщан або купців і займались здебільшого торгівлею, сільським господарством та видобутком черепашнику. Серед основних місць їх розселення був Пересип.

Питання заселення українськими козаками Пересипу частково розглядалося в працях дослідників XIX ст. Вони відзначали, що українське населення, значну частину якого становили запорозькі козаки, проживало на околицях Хаджибею ще в 70-х рр. XVIII ст. Зокрема, протоієрей С. Петровський писав, що на околицях Хаджибею проживав значний відсоток запорозьких козаків, які з 1775 р. за дозволом паші поселилися по балках: Нерубайське, Усатове та частково на Пересипу [15, с. 3.]. О. Маркевич стверджував, що ці околиці були густо заселені ще в 70-80-ті pp. XVIII ст. в основному українцями, які були досить заможними, займалися сільським господарством, городництвом, рибальством, видобутком солі з лиманів тощо. До того ж вони вели жваву торгівлю, поставляючи в Хаджибей продукти харчування [11, с. 126].

У сучасній українській історіографії з'явились дослідження, автори яких торкаються проблеми появи козаків на околицях Хаджибею та в передмісті Одеси. А. Д. Бачинський зазначав, що надзвичайно важливу роль у будівництві ХаджибеюОдеси протягом 1794-1797 pp. відіграли козаки, які були у Чорноморській гребній флотилії Й. Дерибаса. У відповідності з Генеральним планом Одеси 1798 р. для проживання чорноморських козаків відводилось так звана «Чорноморська слобідка» на Пересипу, де в подальшому планувалось будівництво Чорноморської церкви [1, с. 50].

Група одеських науковців у 2008 р. видала збірку «Одеса козацька», до якої увійшли й наукові розвідки Т. Гончарука та С. Гуцалюк, що стосуються питання появи чорноморських козаків в Хаджибеї-Одесі [13]. Особливий інтерес у контексті даного дослідження становить публікація «Генерального плана топографического города Одессы, крепости и порта, в каком ныне состоянии находится. 1798 г.». Згідно 
3 планом на Пересипу під номером 12 означена «Чорноморська слобода», а під номером 14 - майбутня Чорноморська церква [13, с. 60-61].

Проблемі запорозьких i чорноморських козаків у Хаджибеї та Одесі присвячено дослідження I. Сапожникова та Г. Сапожникової. Дослідники, зокрема, важають, що кількість козаків та їх родичів, які поселилися в 1797 р. в Одесі, сягала від 400 до 450 осіб, що становило майже 10\% від загальної кількості жителів міста $[16$, c. 73$]$.

Про певний зв’язок козаків з Пересипом згадував у своїй книзі О. Олійників, зазначавши, що «Саме до Хаджибейського Пересипу молодий запорозький козак у 1709 р. приніс Образ Покрови Пресвятої Божої Матері Непорочної Діви Марії, урятувавши його від полум'я» [14, с. 33].

В. Михальченко, який досліджує біографістику одеського духовенства, надав короткі біографічні довідки й тих священиків, які служили в міському храмі Казанської ікони Божої Матері [10].

У своєму монографічному дослідженні, яке стосується православного життя в Одесі упродовж 1917-1945 pp., М. Михайлуца згадував і про Казанську церкву на Пересипу, якої торкнулися усі перипетії того буремного часу [12].

Однак дослідники не розглядали проблему заснування та розбудови козацької церкви на Пересипу. 3 приємнісю можна зазначити, що протоієрей Одеського храму Казанської ікони Божої Матері Сергій Каюн підготував до друку книгу, яка стосується історії храму - «Духовный маяк Пересыпи», яку незабаром планує опублікувати (упорядник - одеський краєзнавець О. Чилей). Проте на даний період часу в історичній літературі бракує праць, присвячених історії храму, що робить представлену публікацію, яка виконана в руслі краєзнавчої тематики, достатньоо актуальною.

Мета статті полягає у висвітленні основних аспектів розбудови Одеського храму Казанської ікони Божої Матері в контексті його досягнень та проблем упродовж XVIII - кінця XX ст.

Козаки, які з кінця XVIII ст. проживали в передмісті Хаджибею-Одеси - на Пересипу, стали парафіянами трьох одеських православних церков, які знаходились в центрі міста. Тож на рубежі XVIII - XIX ст. постало питання про необхідність будівництва церкви в цьому районі. У Державному архіві Одеської області зберігаються документи, за допомогою яких можна репрезентувати непростий процес перемовин жителів Пересипу з світською та духовною владою Одеси щодо розбудови храму. Це, зокрема, звернення депутатів від цього району до генерал-губернатора графа М. С. Воронцова від 10 січня 1833 р. 3 проханням затвердити поданий ними план церкви Казанської Божої Матері та надати зручну ділянку землі під іiі будівництво [2, арк. 1]. Проте вказане звернення було подане без попереднього узгодження питання 3 правлячим архієреєм Димитрієм (Сулимою), що викликало незадоволення останнього.

Лише 28 вересня 1835 р. архієпископ повідомив Одеського градоначальника O. I. Левшина про те, що до нього з клопотанням про будівництво церкви Казанської Божої Матері звернулися депутати від Пересипу - купці Микола Кушнірьов, Дмитро Філіпов та Ієрофей Бондарєв. Вони надали план і фасад майбутньої церкви й обгрунтували ¥ї необхідність. Насамперед, у передмісті Пересипу проживають парафіяни трьох одеських церков: соборної Преображенської, Покровської й Успенської, загальною чисельністю 591 особа чоловічої статі та 5324 особи жіночої. Дорога до найближчої Преображенської церкви в негоду, особливо навесні та восени, 
розмита і пересуватися нею досить проблематично. До того ж у цьому передмісті проживає значна кількість розкольників, наявність церкви для яких може прискорити навернення в православ'я. Враховуючи усе вище зазначене, Димитрій (Сулима) звернувся до градоначальника 3 проханням призначити чиновника, який би разом 3 Одеським старшим благочинним протоієреєм Іоаковом Сотниченком грунтовно вивчили питання доцільності будівництва церкви [9, арк. 1-2].

Проте навіть вивчення питання затяглося на роки. Справа дещо пожвавилась коли Одеса стала кафедральним містом новоутвореної Херсонсько-Таврійської єпархії, яку очолив архієпископ Гавриїл (Розанов). Головна проблема на шляху спорудження церкви полягала в пошуках коштів. На середину 1842 р. існувало три проєкти майбутньої церкви. Перший із них був представлений депутатами від жителів Пересипу. Він складався 3 плану, фасаду і кошторису в 36172 крб. 20 1/2 коп. асигнаціями, проте він не був схвалений Головним управлінням шляхів сполучення $\mathrm{i}$ публічних приміщень. Другий проєкт був складений самою комісією Головного управління. Він складався 3 плану і фасаду у візантійському стилі, але не мав кошторису. На думку Гавриїла (Розанова) він міг обійтися в 60 тис. крб. Третій проєкт, за дорученням М. С. Воронцова, був підготовлений міським архітектором Г. Торрічеллі. Кошторис був складений у відповідності до зроблених ним креслень і переданий до Будівельного комітету [2, арк. 32, 51].

10 липня 1843 р. архієпископ отримав указ Св. Синоду, згідно з яким дозволялось будівництво кам'яної церкви на Пересипу. На будівництво виділялось кошти в кредит на 20 років під розписку попечителя купця Мелованова [2, арк. 55, 61, 65].

Церкву Казанської ікони Божої Матері на Пересипу закладено в 1844 р., побудовано на кошти парафіян й освячено 21 листопада 1846 р. Тоді ж Херсонською Духовною Консисторією церкві була видана метрична книга. Варто зазначити, що в документах XIX ст. церква здебільшого має назву «Казанська церква на Пересипу», рідше - «церква Казанської Божої Матері». У метричній книзі уже в 1846 р. зроблено перші записи, які засвідчують, що в листопаді - грудні серед парафіян церкви народилося 29 дітей і померло 19 осіб [5, арк. 445-489 зв.].

Церква була кам'яною, одно-пристольною. Згідно зі штатом при ній мало бути два священика, диякон, дячок і паламар. Проте священиком був лише один Фока Михайлович Левицький, який очолював церкву упродовж 1846-1872 рр. був. Він народився в 1799 р. у сім’ї священнослужителя, в духовній семінарії не навчався, тож спеціальної освіти не мав. Проте це не завадило йому зробити певну церковну кар'єру і поступово пройти шлях від паламаря до священика. У 1808 р. Катеринославським архієпископом Платоном (Любарським) його призначено в поміщицьке село Покровське паламарем Петро-Павлівської церкви, в 1816 р. переведено до поміщицького села Ковалівки дячком до Свято-Михайлівської церкви, а в 1829 р. - до Одеського кафедрального Преображенського собору. Згодом, у 1837 р. він став дияконом цього ж собору. 30 січня 1839 р. Ф. Левицький був висвячений в сан священика собору, а в 1846 р. його переведено священиком до Казанської церкви на Пересипу, служіння якій він присвятив решту свого життя.

Дияконом церкви 26 листопада 1846 р. призначено Олександра Івановича Гребенникова. Дячком став 25-річний Семен Фомич Камінський. Паламарем у листопаді 1946 р. призначено Олександра Миколайовича Фоміна [3, арк. 45-48].

Серед перших парафіян церкви переважну більшість становили колишні козаки, які здебільшого були записані до станів міщанства та купецтва. У 1848 р. до парафіян церкви Казанської ікони Божої Матері належало 1675 осіб: 828 осіб 
чоловічої і 847 осіб жіночої статі. Зокрема, 18 осіб духовного звання, 68 чиновників, 14 почесних громадян міста, 47 одеських купців, 787 міщан, 540 іногородніх, 28 нижніх чинів і 146 розкольників [3, арк. 49]. Слід зазначити, що в церковних документах під терміном “розкольники” часто фігурували як старовіри, так i представники низки сект: молокани, духобори скопці та інші. Офіційно до 1905 р. розкольниками називали прихильників старообрядництва або старовірів.

3 часом освітній рівень духовенства, яке служило в церкві Казанської ікони Божої Матері, стає більш високим. Наступним священиком після Ф. Левицького став Федір Федорович Чемена, який служив там з 1872 по 1894 рр. і зробив вагомий внесок у подальший розвиток парафії. Він був родом із Подільської губернії, тож навчався спочатку в Подільській духовній семінарії, потім перевівся до Херсонської духовної семінарії після закінчення якої (1861р.) був призначений законовчителем до дівочого училища при Одеському Архангело-Михайлівському жіночому монастирі. У 1862 р. він прийняв сан священика й служив спочатку в церквах Одеського повіту, а в 1872 р. Ф. Чемена був переведений священиком до церкви Казанської ікони Божої Матері. У 1894 р. його призначено до Успенської церкви, де він недовго встиг прослужити до своєї смерті (6 липня 1894 р.) [10, с. 504]. Його рідний брат Мартирій Федорович Чемена теж немало прислужився місту. Після успішної священницької діяльності він упродовж 1868-1900рр. здійснював плідне керівництво Одеською духовною семінарією.

У церковних документах за 1875 р. зазначено, що до парафіян церкви Казанської ікони Божої Матері належали 20 осіб духовного звання, 199 військових, 29 штатських, 744 купців і міщан та 113 розкольників [4, арк. 134]. Тож основну частину парафіян, як і раніше, складали колишні козаки, які дбали про розвиток своєї парафії. Спільними зусиллями парафіян та церковнослужителів у 1888 р. при церкві відкрито однокласну церковно-парафіяльну школу, де діти могли отримати початкову освіту. Організація навчального процесу та благодійність здійснювались за добровільні пожертвування парафіян.

У $1889-1896$ pp. настоятелем храму Казанської ікони Божої Матері був протоієрей Антоній Йосипович Гентус, який в 1865 р. закінчив Одеську духовну семінарію й рік після того прийняв сан священика. Спочатку він служив у храмах Одеського й Херсонського повітів та в Бериславі, звідки в 1889 р. його перевели до Одеси, до церкви Казанської ікони Божої Матері [10, с. 106]. А. Гентус доклав чимало зусиль для подальшої розбудови храму. У 1895 р. його значно розширили й добудували дзвіницю. Він став дво-престольний: головний престол називався в честь Казанської ікони Божої Матері, а другий - в честь Трьох Святителів. При храмі в 1897 р. організовано парафіяльне попечительство та недільна школа.

У XX ст. в історії храму Казанської ікони Божої Матері можна виокремити декілька періодів. Перший із них, найбільш успішний, розпочався в 1900 р. і тривав приблизно до початку 1920-х рр. У цей час до штату церкви входили два священики і два паламарі. Упродовж 1896-1911 pр. настоятелем церкви був протоієрей Іоанн Олександрович Шрамков, який свого часу закінчив Курську духовну семінарію. Одночасно він здійснював керівництво церковно-парафіяльною школою. Його плідна діяльність відзначена низкою нагород, у тому числі й орденом св. Анни 3-го ступеня.

Другим священиком 31900 по 1913 рр. служив Микола Михайлович Чередєєв. Він походив з дворян Тверської губернії. Навчався спочатку в Донській духовній семінарії, а потім перевівся до Одеської, яку успішно закінчив у 1888 р. У 1896 р. прийняв сан священика й був призначений до Миколаївського собору м. Бобринець. 
За плідну працю в Одеському відділі Імператорського Православного Палестинського товариства в 1899 р. став його пожиттєвим дійсним членом. 14 березня 1900 р. отримав призначення на вакантну посаду другого священика до храму Казанської ікони Божої Матері, де й прослужив до кінця свого життя. У цей час він успішно поєднував церковну діяльність 3 освітянською, працюючи законовчителем в народних училищах № 11 та 12 у домі Трігера на Московській вулиці, які належали до компетенції церкви [10, с. 507, 528 - 529].

Паламарями в зазначений період часу були Петро Кирилович Боруцький (з 1898 р.) і Сергій Никонович Мирошниченко (з 1905 р.).

У метричній книзі храму за 1900 р. зафіксовано народження 662-х немовлят. Шлюб у цей час взяли 250 осіб. Звертає на себе увагу той факт, що вінчалися особи, які належали до різних станів, національностей і навіть віросповідань. Серед молодят були міщани, селяни Подільської губернії, вільні матроси та інші. Один із наречених був Турецький підданий. 29 вересня 1900 р. протоієрей Іоанн Шрамков вінчав колишнього підданого Німеччини Іоанна Кюнера, який належав до лютеранського віросповідання, 3 православною дочкою миколаївського міщанина, 20-річною Степанидою Олексіївною Вольською [6, арк. 121, 150, 184].

У відповідності з довідником Херсонської єпархії за 1906 р. до парафії храму Казанської ікони Божої належало 287 дворів, а загальна чисельність парафіян становила 2158 осіб. Церковний капітал складав 1800 крб. Церква опікувалась чотирма міськими народними училищами і однокласною церковною школою [17, с. 28-29].

У період з 1913 по 1919 рр. настоятелем храму був Петро Васильович Брилєв, який в 1888 р. закінчив Одеську духовну семінарію. До призначення в храм Казанської ікони Божої Матері він поєднував церковну і освітянську діяльність в різних місцях Херсонської єпархії [10, с. 58]. Початок його перебування на чолі храму був досить сприятливим. Кількість парафіян мала чітку теденцію до зростання. У Метричній книзі за 1913 р. зафіксовано, що народилось 662 особи, вінчалося 256 осіб та померло 111 осіб. Найвищою, як і в попередні роки, була дитяча смертність. Зокрема, у віці до одного року померло 38 немовлят, а від одного до п'яти років - 13 дітей [7, арк. 258]. Проте подібна статистика була характерною для Російської імперії і пояснювалась недостатнім доглядом за дітьми, особливо в бідних сім'ях.

У непростому для країни 1918 р. основні показники парафії були менш втішними. У цей рік народилося 537 немовлят та померло 246 осіб. Дитяча смертність стала вищою: віком до одного року померло 56 дітей, від одного до п'яти років - 20, що на 25 осіб більше, ніж у 1913 р. [8, арк. 238]. Характерною особливістю осені та зими стала смертність парафіян від запалення легенів, чого не спостерігалося влітку. Так у вересні зафіксовано 18 таких випадків (усього померло 33 особи), а в грудні 13 (у цьому місяці померло 49 осіб). Крім того, у грудні під час боїв було вбито 31 особу [8, арк. 207-237]. Попри усі негаразди у церкві в 1918 р. взяли шлюб 229 осіб. Причому, серед парафіянок, що одружувались в цей час, були представниці різних станів. Зокрема: козачка Свдокія Пархоменко, селянка Марія Жуматій, міщанка Олена Олійниченко, дочка особистого почесного громадянина Надія Петровська та інші [8, арк. 139-207].

Революційні події, які відбувались в Одесі, не могли не позначитись на життєдіяльності парафіян храму. Тож у 1919 р. статистичні показники парафії були дещо гіршими, ніж у попередньому році. Народилося лише 222 дитини, одружилося 225 осіб і померло 215 осіб [8, арк. 239-370]. 
3 1920-х до 1936 pp. розпочався другий етап в історії храму. Він віддзеркалював загальну політику радянської влади до релігії в цілому, спрямовану на іiі знищення. Це був час утисків, грабунків і репресій по відношенню до церкви та духовенства. У 1936 р. приміщення храму будо конфісковано владою й там розташували казарми моряків.

Третій період розпочався в період Другої світової війни. У 1941 р. Румунська православна місія одним із першочергових завдань в Одесі вважала повернення відібраного більшовиками майна і власності, які належали єпархіям та церквам, відкриття та освячення діючих та відремонтованих церков тощо. Тож уже в листопаді 1941 р. здійснювалось богослужіння в п'яти церквах міста, в тому числі й в храмі Казанської ікони Божої Матері [12, с. 207]. Проте згодом за розпорядженням радянської влади храм знову був закритий, а в його приміщенні в 1962 р. розмістили магазин меблів.

31991 р. розпочався четвертий період, який характеризується відродженням храму. У відповідь на чисельні прохання приміщення храму повернули віруючим, але воно потребувало значної реконструкції. Завдяки зусиллям деяких парафіян та благочестивій стариці черниці Пантелеймоні, збереглися головні церковні цінності, в тому числі й чудотворна ікона Божої Матері «Живоносне джерело на камені». У 1996 р. митрополит УПЦ Агафангел (Саввін) освятив приміщення храму, а згодом, уже на початку XXI ст. - купола, дзвіницю та новий іконостас. Тож храм Казанської ікони Божої Матері отримав нові можливості для свого подальшого розвитку.

\section{Джерела та література:}

1.Бачинський А. Д. Хаджибей-Одеса і українське козацтво / А. Д. Бачинський // Тези доповідей міжнародної науково-теоретичної конференції 6-8 вересня 1994 р. Одеса, 1994. Ч.1. - С. 49-51.

2. Держархів Одеської області. - Ф. 1. - Оп. 191. - Спр. 71.

3. Держархів Одеської області. - Ф. 37. - Оп. 2а . - Спр. 497.

4. Держархів Одеської області. - Ф. 37. - Оп. 2а. - Спр. 577.

5. Держархів Одеської області. - Ф. 37. - Оп. 3. - Спр. 844.

6. Держархів Одеської області. - Ф. 37. - Оп. 13. - Спр. 370.

7. Держархів Одеської області. - Ф. 37. - Оп. 13. - Спр. 932.

8. Держархів Одеської області. - Ф. 37. - Оп. 13. - Спр. 1205.

9. Держархів Одеської області. - Ф. 59. - Оп. 2. - Спр. 454.

10. Духовенство Одессы / авт.-сост. А. В. Михальченко. - Одесса: «ТЕС», 2012. - 559 с.

11. Історія Хаджибея (Одеси) 1415-1795 pр. в документах / за ред. канд. іст. наук Т. Г. Гончарука. - Одеса: Астропринт, 2000. - 372 с.

12. Михайлуца М. Православне життя в Одесі: від революції до сталінського одержавлення (1917-1945). / М. Михайлуца. - Херсон: Олді-плюс, 2019. - 388 с.

13. Бачинська О. А. Одеса козацька. Наукові нариси / Бачинська О. А., Гончарук Т. Г., Гуцалюк С. Б. - Одеса: Фенікс, 2008. - 240 с.

14. Олійників О. Наснага одеської душі: одеські храми та добродійні товариства і осередки./ О. Олійників - Одеса: Астропринт, 2008. - 240 с.

15. Петровский С. Одесский кафедральный Преображенский собор. / С. Петровский. - Одесса: тип. Е. И. есенко, 1894. -123 с.

16. Сапожников И. В. Запорожские и черноморские казаки в Хаджибее и Одессе. / И. В. Сапожников, Г. В.Сапожникова. - Одесса: ОКФА, 1998. - 270 с.

17. Справочная книга Херсонской епархии. - Одесса, 1906. - 757 с. 


\section{References:}

1.Bachyns'kyy, A. D., 1994. Khadzhybey-Odesa i ukrayins'ke kozatstvo. Tezy dopovidey mizhnarodnoyi naukovo-teoretychnoyi konferentsiyi 6-8 veresnya 1994 r. Odesa, Ch.1, p. 49-51 [in Ukrainian].

2.Derzharkhiv Odes'koyi oblasti (The State Archives of the Odessa region (Ukraine)). F. 1. Op. 191. Spr. 71 [in Russian].

3.Derzharkhiv Odes'koyi oblasti (The State Archives of the Odessa region (Ukraine)). F. 37. Op. 2a. Spr. 497 [in Russian].

4.Derzharkhiv Odes'koyi oblasti (The State Archives of the Odessa region (Ukraine)). F. 37. Op. 2a. Spr. 577 [in Russian].

5.Derzharkhiv Odes'koyi oblasti (The State Archives of the Odessa region (Ukraine)). F. 37. Op. 3. Spr. 844 [in Russian]..

6.Derzharkhiv Odes'koyi oblasti(The State Archives of the Odessa region (Ukraine)). F. 37. Op. 13. Spr. 370 [in Russian].

7.Derzharkhiv Odes'koyi oblasti(The State Archives of the Odessa region (Ukraine)). F. 37. Op. 13. Spr. 932 [in Russian].

8. Derzharkhiv Odes'koyi oblasti(The State Archives of the Odessa region (Ukraine)). F. 37. Op. 13. Spr. 1205 [in Russian].

9. Derzharkhiv Odes'koyi oblasti(The State Archives of the Odessa region (Ukraine)). F. 59. Op. 2. Spr. 454 [In Ukrainian].

10. Mikhal'chenko, A. V., 2012. Dukhovenstvo Odessy. Odessa: «TES», 559 p. [in Russian].

11. Honcharuk, T. H., 2000. Istoriya Khadzhybeya (Odesy) 1415-1795 rr. v dokumentakh. Odesa: Astroprynt, 372 p. [In Ukrainian].

12. Mykhaylutsa, M., 2019. Pravoslavne zhyttya v Odesi: vid revolyutsiyi do stalins'koho oderzhavlennya (1917-1945). Kherson: Oldi-plyus, 388 p. [In Ukrainian].

13. Bachyns'ka, O. A., Honcharuk, T. H. \& Hutsalyuk, S. B., 2008. Odesa kozats'ka. Naukovi narysy. Odesa: Feniks, 240 p. [In Ukrainian].

14. Oliynykiv, O., 2008. Nasnaha odes'koyi dushi: odes'ki khramy ta dobrodiyni tovarystva $i$ oseredky. Odesa: Astroprynt. 240 p. [In Ukrainian].

15. Petrovskiy, S., 1894. Odesskiy kafedral'nyy Preobrazhenskiy sobor. Odessa : tip. E. I. Fesenko, 123 p. [in Russian].

16. Sapozhnikov, I. V. \& Sapozhnikova, G. V., 1998. Zaporozhskie i chernomorskie kazaki v Khadzhibee i Odesse. Odessa: OKFA, 270 p. [in Russian].

17. Spravochnaya kniga Khersonskoy eparkhii, 1906. Odessa, 757 p. [in Russian].

Отримано: 02.12.2020 p. 